\title{
Earthquake and tsunami potential levels in Sulawesi (lesson learned earthquake West Sulawesi)
}

\author{
Rio Khoirudin Apriyadi ${ }^{*}$, Sobar Sutisna ${ }^{1}$, Lasmono $^{1}$, and Riskina Tri Januarti ${ }^{1}$ \\ ${ }^{1}$ Disaster Management Study Program, National Security Faculty, Republic of Indonesia Defense University. IPSC Sentul Area, \\ Bogor, West Java, Indonesia
}

\begin{abstract}
Earthquake and tsunami disasters always bring negative impacts and losses for humans. The high frequency of earthquake disasters in Sulawesi and the massive impact of destruction and damage to infrastructure, loss of homes and property, and death of people are partly due to the lack of knowledge of this potential disaster by the surrounding community. Therefore, it is necessary to study the potential for earthquake and tsunami disasters on Sulawesi Island, and Lesson Learned about the Earthquake Disaster that has occurred in past. This study uses a qualitative method with a descriptive analysis design of secondary data obtained through a comprehensive literature review. The results showed that Sulawesi Island has a high potential for earthquake disasters, which is in the historical records of disasters, some of these earthquakes were accompanied by tsunami waves. The lesson that can be drawn from the earthquake in West Sulawesi is the potential for aftershocks after the opening earthquake and the main earthquake. In addition, the urgency of building earthquakeresistant housing structural mitigation is the key to safety during an earthquake. The post-earthquake recovery program in West Sulawesi requires further studies related to soil classification surveys, soil dominant periods, and soil seismic vulnerability index, as part of rebuilding a better and safer postdisaster area.
\end{abstract}

\section{Introduction}

The earthquake disaster in early 2021 that occurred in Mamuju Regency and Mejene Regency shocked the people of Indonesia, amid the non-natural disaster the Covid-19 pandemic. On Thursday, January 14, 2021, Mamuju Regency and Majene Regency experienced a large earthquake with M 5.9 on the Richter scale at a depth of $10 \mathrm{~km}$ whose epicenter was on land $4 \mathrm{~km}$ northwest of Majene. The next earthquake shook the area again with a magnitude of M 6.2 at a depth of $10 \mathrm{~km}$ at a location $6 \mathrm{~km}$ northeast of Majene [1].

This main earthquake was followed by a series of aftershocks with magnitude of between 1 SR and 6.2 SR (Fig. 1).

Based on data from the National Disaster Management Agency (BNPB), as of January 21, the earthquake had killed 51 people ( 8 people in Majene Regency and 34 people in Mamuju Regency), as many as 556 people were injured (189 seriously injured and 367 people injured). people were lightly injured), and 1500 people were evacuated. Losses due to this earthquake are estimated to reach Rp. 829.1 billion [1].

The massive impact and the high frequency of earthquakes on Sulawesi Island are not new in the world of research. Tectonically, Sulawesi Island has more than
45 sources of active fault earthquakes due to collisions between the Eurasian, Indo-Australian, Pacific, and Philippine Sea plates [3]. However, the earthquake that occurred during the Covid-19 pandemic directly increased the risk of spreading Covid-19 in the disaster cluster. This is not accompanied by an increase in capacity and knowledge about disaster risk on the island of Sulawesi.

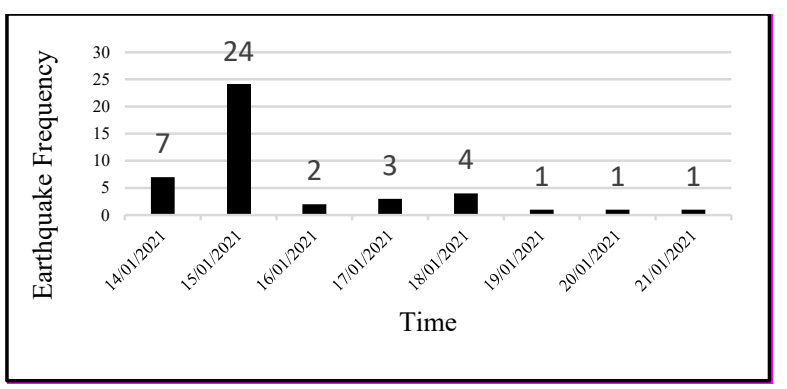

Fig. 1. Frequency of Destructive Earthquakes in Majene and Mamuju Regencies in the Period of January 14, 2021, to January $21,2021$.

This paper, besides aiming to describe the potential for earthquake and tsunami disaster on Sulawesi Island, but also describes lessons that can be drawn from the

\footnotetext{
*Corresponding Author: riokapriyadi@gmail.com
} 
earthquake disaster in Mamuju Regency and Mejene Regency, West Sulawesi in early 2021.

The significance of this research is it is important to carry out immediate measurements in the prone earthquakes area such as on the island of Sulawesi. The results of this analysis are used as database and lesson learnt in the implementation of disaster risk reduction policies in Indonesia.

\section{Method}

We use a qualitative method with a descriptive analysis design as an analytical tool in answering research problems. The data in this study were obtained through a literature study.

We use Shakemap Repository data obtained from the Meteorology, Climatology and Geophysics Agency (BMKG), Indonesia earthquake source and hazard maps from the National Earthquake Study Center (PUSGEN), a catalog of destructive earthquakes in Indonesia by the Center for Volcanology and Geological Hazard Mitigation (PVMBG), The National Tsunami Hazard Study for Indonesia by the Meteorology, Climatology and Geophysics Agency (BMKG), the Indonesia Disaster Risk Index by BNPB, and other documents related to the potential for earthquakes and tsunamis in Sulawesi, as well as a Situation Report on Earthquake Management in West Sulawesi [2-5].

\section{Result and discussion}

\subsection{Earthquake Potential on Sulawesi Island}

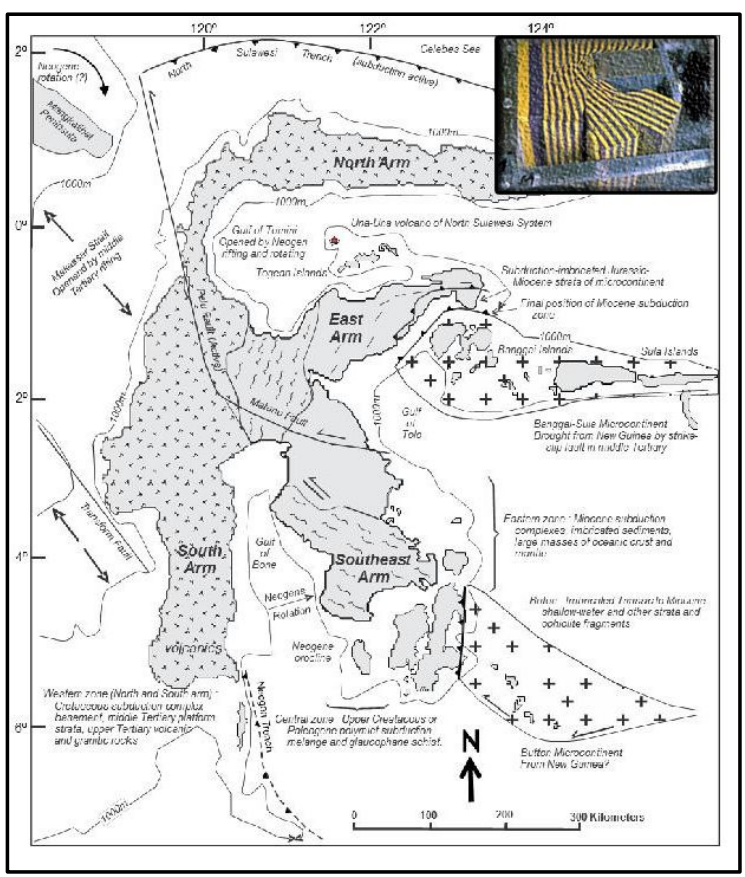

Fig. 2. Sulawesi Tectonic Dynamics Due to Intercontinental Push [10-12].

Sulawesi Island has the potential for earthquakes due to the complex and complex tectonic setting. Several studies reveal that some of the tectonic dynamics of the formation of this island due to the thrust between the Eurasian, Indo-Australian, Pacific, and Philippine Sea plates make the appearance of this island similar to the letter K (Figure 2), resulting in this island having many sources of active fault earthquakes on this island (Figure 3) [6-9].

Figure 2 explains that the formation of Sulawesi Island has a complicated fault structure consisting of faults that are still actively moving and no longer moving. The fault segment that forms the island of Sulawesi can be seen in Fig 3.

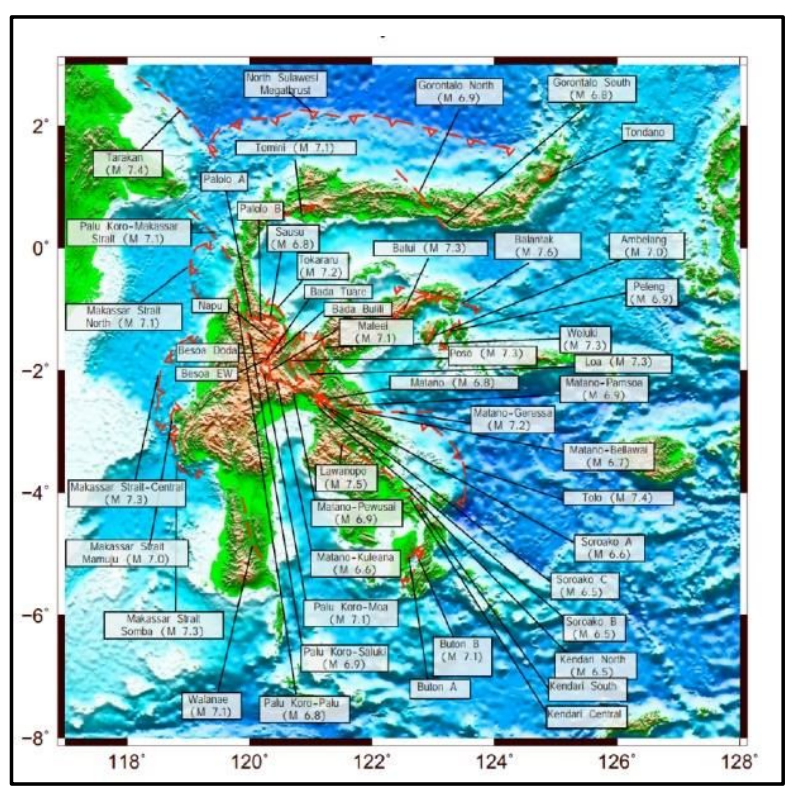

Fig. 3. Active Fault Segment on Sulawesi Island [3].

Figure 3 illustrates that Sulawesi Island has more than 45 active fault segments which are the source of earthquakes on this island [3]. Details of the active fault segments summarized in the 2017 National Earthquake map above can be seen in Table 1 .

Table 1. Sulawesi Island Active Fault Segment

\begin{tabular}{|c|c|c|}
\hline Structure Name & Section & $\begin{array}{c}\text { Max } \\
\text { Length } \\
\text { (km) }\end{array}$ \\
\hline Palukoro Fault & Makasar Str & 130 \\
\hline Palukoro Fault & Palu & 31 \\
\hline Palukoro Fault & Saluki & 44 \\
\hline Palukoro Fault & Moa & 66 \\
\hline Matano Fault & Kuleana & 22 \\
\hline Matano Fault & Pewusai & 46 \\
\hline Matano Fault & Matano & 35 \\
\hline Matano Fault & Pamsoa & 44 \\
\hline Matano Fault & Ballawai & 26 \\
\hline Matano Fault & Geressa & 80 \\
\hline Soroako Thrust & A & 24 \\
\hline Soroako Thrust & B & 20 \\
\hline Soroako Thrust & C & 16 \\
\hline Batui Thrust & - & 84 \\
\hline Balantak & - & 149 \\
\hline Makasar Strait Thrust & North & 100 \\
\hline Makasar Strait Thrust & Central & 170 \\
\hline \multicolumn{2}{|c}{} & \\
\hline & \multicolumn{2}{|c|}{} \\
\hline
\end{tabular}




\begin{tabular}{|c|c|c|}
\hline Structure Name & Section & $\begin{array}{c}\text { Max } \\
\text { Length } \\
(\mathbf{k m})\end{array}$ \\
\hline Makasar Strait Thrust & Mamuju & 40 \\
\hline Makasar Strait Thrust & Somba & 80 \\
\hline Buton & $\mathrm{A}$ & 29 \\
\hline Buton & $\mathrm{B}$ & 60 \\
\hline Palolo & $\mathrm{A}$ & 29 \\
\hline Palolo & $\mathrm{B}$ & 24 \\
\hline Bada Valley Fault & Tuare WSW & 16 \\
\hline Bada Valley Fault & Bulili NNE & 26 \\
\hline Besoa Valley Fault & EW & 7 \\
\hline Besoa Valley Fault & Doda NW & 7 \\
\hline Peleng & - & 44 \\
\hline Ambelang & - & 50 \\
\hline Sausu & - & 31 \\
\hline Tokararu & - & 80 \\
\hline Tondano & - & 30 \\
\hline Poso & - & 85 \\
\hline Loa & - & 86 \\
\hline Weluki & - & 72 \\
\hline Tomini & - & 59 \\
\hline Lawanopo & - & 130 \\
\hline Tolo Thrust & - & 120 \\
\hline Gorontalo & North & 74 \\
\hline Gorontalo & South & 70 \\
\hline Walanae & - & 130 \\
\hline Kendari Fault & North & 24 \\
\hline Kendari Fault & Central & 11 \\
\hline Kendari Fault & South & 10 \\
\hline North & - & 550 \\
\hline Megathrust & - & 0 \\
\hline $\mathrm{Napu}$ & - & 11 \\
\hline Tarakan & - & 206 \\
\hline Maleei & - & 70 \\
\hline
\end{tabular}

The number of active fault segments on Sulawesi Island is directly proportional to the high Earthquake Disaster Risk Index in 2020 issued by the National Disaster Management Agency (BNPB) which states that all provinces on Sulawesi Island, which include Gorontalo Province, West Sulawesi Province, South Sulawesi Province, Southeast Sulawesi Province, Central Sulawesi Province, and North Sulawesi Province have an Earthquake Disaster Risk Index with high criteria. Another interesting fact is that several districts or cities on Sulawesi Island have the highest earthquake risk index in Indonesia, such as the Bangai Laut Regency, the North Morowali Regency, and the West Muna Regency with a score of 36.0 (High-Risk Class) $[5,13]$.

\subsection{Potential Tsunami on Sulawesi Island}

Based on the Indonesian Disaster Data and Information Management Database which was developed using the software and methodologies DesInventar and DesConsultar by the National Disaster Management Agency (BNPB), states that districts or cities on Sulawesi Island have a variety of Tsunami Disaster Risk Indexes, ranging from moderate to high-risk classes. with height [5].

Several studies have simulated the probability of a large tsunami with a run-up of more than 3 meters, with a probability of occurrence and a return period of 100 years on Sulawesi Island [14], as can be seen in Table 2.

Table 2. Annual Tsunami Probability and Annual Tsunami Run-up Every 100 Years Return Period on Sulawesi Island

\begin{tabular}{|c|c|c|}
\hline Districts & $\begin{array}{c}\text { Annual } \\
\text { Tsunami } \\
\text { Probability } \\
\text { Tsunami }\end{array}$ & $\begin{array}{c}\text { Tsunami } \\
\text { Run-up } \\
\text { Every 100 } \\
\text { Years }\end{array}$ \\
\hline Bitung City & $1,1 \%$ & 3,2 \\
\hline Sangihe Islands & $1,0 \%$ & 2,9 \\
\hline North Minahasa & $1,0 \%$ & 2,9 \\
\hline Talaud Islands & $0,9 \%$ & 2,8 \\
\hline Manado City & $0,9 \%$ & 2,7 \\
\hline Buol & $0,9 \%$ & 2,7 \\
\hline South Minahasa & $0,8 \%$ & 2,7 \\
\hline Minahasa & $0,8 \%$ & 2,5 \\
\hline Toli-Toli & $0,7 \%$ & 2,4 \\
\hline Bolaang Mengondow & $0,5 \%$ & 2,1 \\
\hline Konawe & $0,5 \%$ & 1,9 \\
\hline Muna & $0,3 \%$ & 1,8 \\
\hline Islands Banggai & $0,3 \%$ & 1,5 \\
\hline Majene & $0,3 \%$ & 1,2 \\
\hline Mamuju & $0,2 \%$ & 1,6 \\
\hline South Konawe & $0,2 \%$ & 1,5 \\
\hline Banggai & $0,2 \%$ & 1,3 \\
\hline Palu & $0,2 \%$ & 1,7 \\
\hline Boalemo & $0,2 \%$ & 1,0 \\
\hline Bone Bolango & $0,2 \%$ & 1,1 \\
\hline Donggala & $0,2 \%$ & 1,7 \\
\hline North Mamuju & $0,2 \%$ & 1,6 \\
\hline Kendari City & $0,2 \%$ & 1,4 \\
\hline Morowali & $0,2 \%$ & 1,3 \\
\hline Wakatobi & $0,2 \%$ & 1,6 \\
\hline Buton & $0,1 \%$ & 1,3 \\
\hline Polmas & $0,1 \%$ & 1,0 \\
\hline Pinrang & $0,1 \%$ & 1,0 \\
\hline Tojo Una - Una & $0,1 \%$ & 0,7 \\
\hline Poso & $0,1 \%$ & 0,7 \\
\hline Barru & $0,1 \%$ & 0,8 \\
\hline Bantaeng & $<0,1 \%$ & 0,7 \\
\hline Jeneponto & $<0,1 \%$ & 0,7 \\
\hline Parigi Moutong & $<0,1 \%$ & 0,6 \\
\hline Pare-Pare & $<0,1 \%$ & 0,8 \\
\hline Bombana & $<0,1 \%$ & 0,8 \\
\hline Bone & $<0,1 \%$ & 0,6 \\
\hline Bulukumba & $<0,1 \%$ & 0,7 \\
\hline Luwu & $<0,1 \%$ & 0,3 \\
\hline East Luwu & $<0,1 \%$ & 0,2 \\
\hline North Luwu & $<0,1 \%$ & 0,2 \\
\hline Maros & $<0,1 \%$ & 0,6 \\
\hline Palopo & $<0,1 \%$ & 0,2 \\
\hline Pangkajene Islands & $<0,1 \%$ & 0,6 \\
\hline Selayar & $<0,1 \%$ & 0,6 \\
\hline Sinjai & $<0,1 \%$ & 0,7 \\
\hline Takalar & $<0,1 \%$ & 0,6 \\
\hline Ujung Pandang & $<0,1 \%$ & 0,6 \\
\hline Wajo & $<0,1 \%$ & 0,3 \\
\hline Kolaka & $<0,1 \%$ & 0,4 \\
\hline North Kolaka & $<0,1 \%$ & 0,3 \\
\hline Bitung City & $1,1 \%$ & 3,2 \\
\hline Sangihe Islands & $1,0 \%$ & 2,9 \\
\hline North Minahasa & $1,0 \%$ & 2,9 \\
\hline
\end{tabular}


Table 2 shows that districts or cities located within 5 kilometers of the coast on Sulawesi Island will experience a tsunami warning with a run-up of more than 3 meters in any year.

Indonesia's disaster history records that in the period 1820 to 2021, West Sulawesi at least had an earthquake accompanied by a tsunami in 1820, 1969, and 1976 [1], as illustrated in Table 3 .

Table 3. Indonesia's disaster history record period 1820 to 2021

\begin{tabular}{|c|c|}
\hline Time & Disaster Type \\
\hline 1820 & Earthquake with Tsunami \\
\hline Feb 23, 1969 & Earthquake with Tsunami \\
\hline Apr 11, 1976 & Earthquake with Tsunami \\
\hline Jan 8, 1984 & Earthquake \\
\hline Jan 14-152021 & Earthquake \\
\hline
\end{tabular}

\subsection{Lesson Learned West Sulawesi Earthquake}

An earthquake in early 2021 occurred in Mamuju Regency and Majene Regency, West Sulawesi Province, is strongly suspected trigger by Mamuju Rising Fault (Mamuju Thrust). The results of the analysis of the source mechanism show that the earthquake has a thrust fault mechanism. This upward fault mechanism is similar to the 2018 Lombok earthquake generator, the fault plane forms the slope of the fault plane to the mainland. The Naik Mamuju Fault has a targeted magnitude of 7.0 with a fault shear rate of $2 \mathrm{~mm} / \mathrm{year}$, so this active fault must be watched out for because it can trigger strong earthquakes.

Characteristics of the type of earthquake that occurred in West Sulawesi is type of earthquake opening (foreshocks), main earthquake (mainshock), and aftershocks (aftershocks). In general, this means that whenever a major earthquake occurs, there will be a main earthquake and aftershocks, as happened on January 14152021 in Majene and Mamuju, West Sulawesi [15,16], as can be seen in Figures 4 and 5 .

Figures 4 and 5 provide lessons learned that aftershocks will occur along with a large earthquake (M > 3 SR). Therefore, awareness of the characteristics of the opening earthquake, main earthquake, and aftershocks needs to be increased. Aftershocks will still occur as usual after a strong earthquake occurs, for that the public is asked to be aware of the possibility of aftershocks of significant strength.

The next lesson learned that we can take from the West Sulawesi earthquake is that we have not made much progress in structural mitigation, such as earthquakeresistant houses. Earthquake-resistant houses are the key to safety during an earthquake. Without any real effort to build earthquake-resistant houses, our community will always be victims when a strong earthquake occurs.

The third lesson learned is related to the postearthquake rehabilitation and reconstruction in Mamuju Regency and Majene Regency, West Sulawesi Province. Post-disaster rehabilitation and reconstruction activities are programs to restore the lives and livelihoods of communities affected by the disaster, because before the construction of permanent housing for post-earthquake victims in Majene Regency and Mamuju Regency, West Sulawesi Province, a survey of land classification, soil dominant period and soil seismic vulnerability index, as part of rebuilding a better and safer post-disaster area.

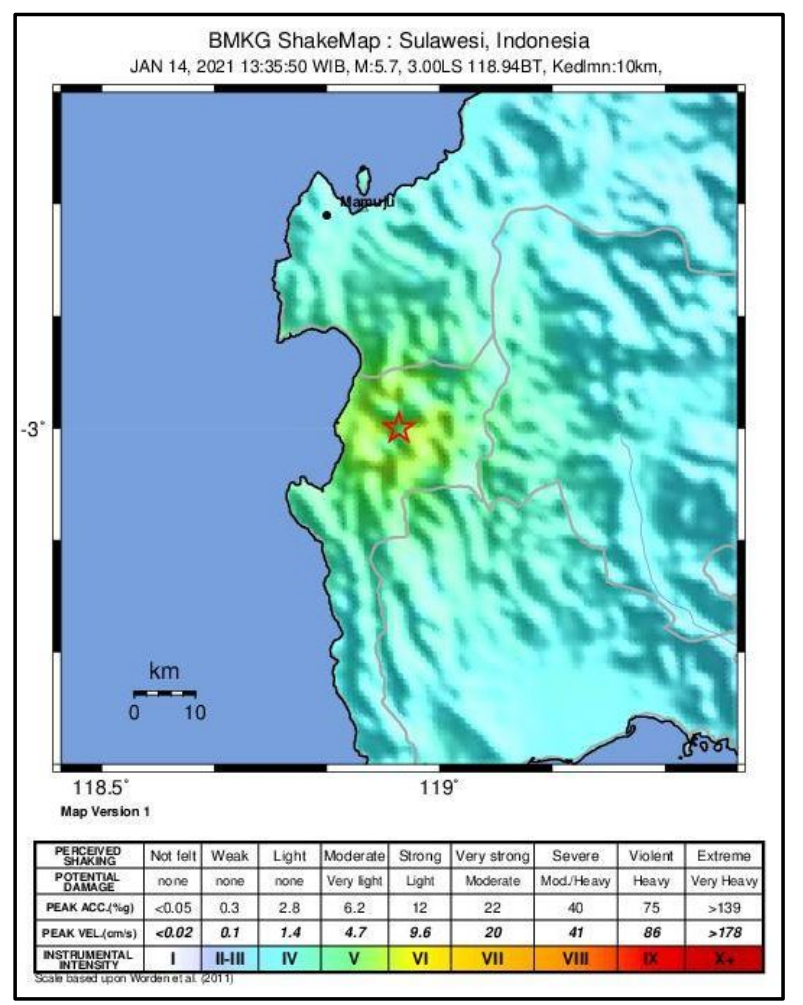

Fig 4. ShakeMap Opening M 5.9 SR

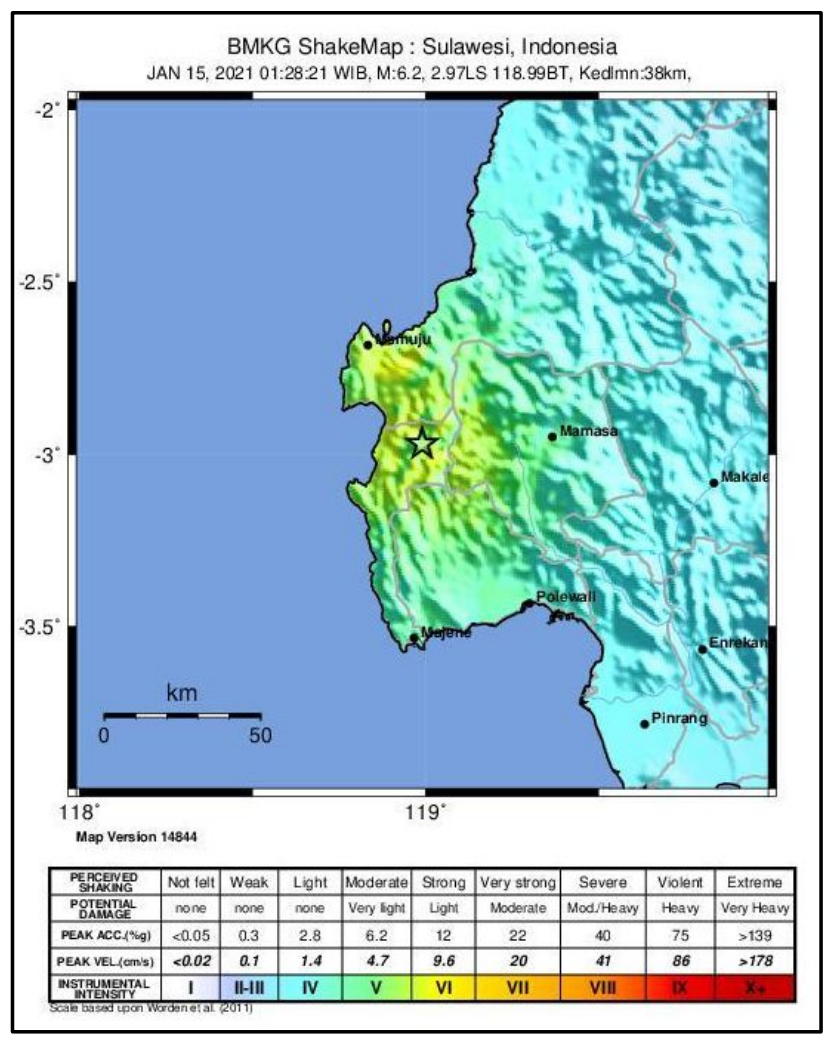

Fig 5. ShakeMap M 6.2 Main Earthquake 


\section{Conclusion}

In conclusion, this study finds that Sulawesi Island has the potential for destructive earthquakes with a high-risk index in all districts or cities spread across the island. The high potential for earthquakes that occur on the island of Sulawesi is the result of the thrust between the plates, resulting in this island having many sources of active fault earthquakes. The source of an active fault earthquake on the island of Sulawesi, besides causing a high frequency of earthquakes, also has the potential for a tsunami disaster to occur in areas located within 5 kilometers of the coast on the island of Sulawesi with a run-up of more than 3 meters.

The history of disasters on Sulawesi Island, such as the earthquake that occurred in West Sulawesi, warns us that structural mitigation, such as earthquake-resistant houses, is the key to safety during an earthquake. Without any structural mitigation efforts such as building earthquakeresistant houses, it is predicted that there will be a spike in fatalities due to the earthquake on Sulawesi Island.

Characteristics of the earthquake that occurred on the island of Sulawesi is a type of earthquake with the type of opening earthquake, main earthquake, and aftershocks. Therefore, whenever a destructive earthquake occurs, it is necessary to watch out for a major earthquake and aftershocks with greater strength.

The lesson that can be taken is the need for future studies related to soil classification surveys, soil dominant periods, and soil seismic vulnerability index as part of the program to restore the lives and livelihoods of disasteraffected communities on Sulawesi Island that can reduce disaster risk in the community, better development and safer.

\section{References}

1. D. Hartono, R. Khoirudin Apriyadi, T. Winugroho, A. Aprilyanto, S. Hadi Sumantri, W. Wilopo, and H. Surya Islami, PENDIPA J. Sci. Educ. 5, 218 (2021)

2. BMKG, ShakeMap Repository (Meteorology Climatology and Geophysics Council (BMKG), Jakarta, 2021)

3. Tim-PSGN, 2017 Earthquake Source and Hazard Map Book (Center for Housing and Settlement Research and Development Ministry of PUPR, Bandung, 2017).
4. Supartoyo, surono, and e. T. Putranto, catalog of destroying earthquakes in indonesia years 1612 2014 catalog of destroying earthquakes in indonesia years 1612 - 2014 catalog of daming earthquakes in indonesia years 1612 - 2014 (center for vulcanology and geological disaster mitigation (PVMBG, Jakarta, 2014)

5. National Board for Disaster Management, Indonesia Disaster Risk Index 2020 (National Board for Disaster Management BNPB, Jakarta, 2021)

6. I. Watkinson, R. Hall, M. Cottam, I. Sevastjanova, S. Suggate, I. Gunawan, J. Pownall, J. Hennig-Breitfeld, F. Ferdian, D. Gold, S. Zimmermann, A. Rudyawan, and E. Advokaat, Ber. Sedimentol. 23, 21 (2012)

7. R. Hall, Tectonophysics 570-571, 1 (2012)

8. T. Kiyota, H. Furuichi, R. F. Hidayat, N. Tada, and H. Nawir, Soils Found. 60, 722 (2020)

9. H. Hazarika, D. Rohit, S. M. K. Pasha, T. Maeda, I. Masyhur, A. Arsyad, and S. Nurdin, Soils Found. 61, 239 (2021)

10. T. R. Charlton, Nature 319, 394 (1986)

11. P. Tapponnier and P. Molnar, Nature 264, 319 (1976)

12. P. Tapponnier, G. Peltzer, A. Y. Le Dain, R. Armijo, and P. Cobbold, Geology 10, 611 (1982)

13. BNPB, Tsunami Prone Villages/Villages Catalog (High and Medium Hazard Classes) (National Disaster Management Agency (BNPB), Jakarta, 2021)

14. N. Horspool, I. R. Pranantyo, J. Griffin, H. Latief, D. Natawidjaja, W. Kongko, A. Cipta, Bustamam, S. D. Anugrah, and H. K. Thio, National Tsunami Hazard Study for Indonesia (National Disaster Management Agency (BNPB), Jakarta, 2013)

15. P. Supendi, M. Ramdhan, Priyobudi, D. Sianipar, A. Wibowo, M. Gunawan, S. Rohadi, N. Florida, Daryono, B. Prayitno, J. Murjaya, D. Karnawati, I. Meilano, N. Rawlinson, S. Widiyantoro, A. Nugraha, G. Marliyani, K. Palgunadi, and E. Elsera, Earth Planets Sp. 73, (2021)

16. P. Supendi, A. Nugraha, S. Widiyantoro, J. Pesicek, C. Thurber, C. I. Abdullah, Daryono, S. Wiyono, H. Ash Shiddiqi, and S. Rosalia, Geophys. J. Int. 221, (2020) 